\title{
Scholarly

\section{Analysis of the Arabidopsis Mitogen-Activated Protein Kinase Families: Organ Specificity and Transcriptional Regulation upon Water Stresses}

\author{
Khaled Moustafa, ${ }^{1}$ Delphine Lefebvre-De Vos, ${ }^{2}$ Anne-Sophie Leprince, ${ }^{2}$ \\ Arnould Savouré, ${ }^{2}$ and Christiane Laurière ${ }^{1}$ \\ ${ }^{1}$ Institut des Sciences du Végétal, UPR 2355, CNRS, 1 avenue de la terrasse, 91198 Gif s/Yvette Cedex, France \\ ${ }^{2}$ Physiologie Cellulaire et Moléculaire des Plantes, UMR 7180, CNRS, Université Pierre et Marie Curie-Paris 6, \\ Case 156, 4 place Jussieu, 75005 Paris, France \\ Correspondence should be addressed to Christiane Laurière, christiane.lauriere@isv.cnrs-gif.fr \\ Received 2 July 2008; Accepted 6 October 2008
}

\begin{abstract}
The Arabidopsis genome contains $20 \mathrm{MPK}, 10 \mathrm{MKK}, 60 \mathrm{MAP} 3 \mathrm{~K}$, and $10 \mathrm{MAP} 4 \mathrm{~K}$ genes, but the functions of the corresponding proteins are still poorly characterized. To research possible functional MAP kinase modules involved in water stress signalling, original macroarrays were developed for their sensitivity and specificity. The expression patterns of the MPK and MKK gene families, as well as selected key members of the MAP3K and MAP4K families, were studied in relation to organ specificity and to various water stresses. Several kinases of the scarcely studied MPK group containing a TDY activation motif were induced by water stresses. There are four different MPKs (MPK9, MPK11, MPK17, and MPK18), among which three contain the TDY activation motif, and MKK9 and MAP3K6 are induced at the transcriptional level by dehydration, salinity, and hyperosmolarity treatments. They probably constitute MAP kinase key elements involved in water stress signalling.
\end{abstract}

Copyright ( $\odot 2008$ Khaled Moustafa et al. This is an open access article distributed under the Creative Commons Attribution License, which permits unrestricted use, distribution, and reproduction in any medium, provided the original work is properly cited.

\section{Introduction}

Mitogen-activated protein (MAP) kinase signalling is one of the most important and conserved pathways in all eukaryotic organisms from plants to animals. MAP kinases are involved in most cell activities, from cell division to death, including cell differentiation and proliferation, cell growth, as well as environmental stress responses. MAP kinase module is typically composed of at least three protein kinases, MAP kinase kinase kinase (MAP3K), MAP kinase kinase (MAP2K, also called MKK), and MAP kinase (MAPK, also called MPK), which are sequentially activated by phosphorylation. Following a stimulus, MAP3K will activate an MAP2K by phosphorylation on two serine/threonine residues in the conserved motif $S / T x x x x x S / T$, which, in turn, activates an MAPK by phosphorylation on both threonine and tyrosine residues in the $\mathrm{T}(\mathrm{E} / \mathrm{D}) \mathrm{Y}$ motif [1]. MAP kinases with protein phosphatases function as on or off switchers to regulate the activity of many downstream substrates, such as transcription factors, cytoskeletal proteins, and other protein kinases [2].

In plants, the role of MAP linases remains poorly understood. Most studies were performed at protein and biochemical levels and reported the involvement of only a few MAP kinases in response to environmental stresses in many species like rice [3-5], tobacco [6], tomato [7], alfalfa [8, 9], and Arabidopsis [10]. Expression data are now available for a great number of Arabidopsis genes through microarray databases like genevestigator (https://www.genevestigator .ethz.ch/). However, results concerning signaling proteins like MAP kinases are clearly insufficient, mostly due to their low level of expression.

The completion and analysis of Arabidopsis genome revealed the presence of $20 \mathrm{MPK}, 10 \mathrm{MKK}, 60 \mathrm{MAP} 3 \mathrm{~K}$, and $10 M A P 4 K$ genes for which a new nomenclature was established [1]. Based on sequence alignment, plant $M P K$ family is classified into four groups $(A, B, C, D)$. Members in $\mathrm{A}, \mathrm{B}$, and $\mathrm{C}$ groups have the TEY phosphorylation 
motif, while the D group members possess the TDY motif. Some members of $\mathrm{A}$ and $\mathrm{B}$ groups in A. thaliana and their orthologs in other species have been described to be activated in response to biotic and abiotic stresses [11-16]. Arabidopsis MPK3 and MPK6 (A group) and their orthologs in tobacco (WIPK and SIPK, resp.) are the most extensively studied. MPK3 and MPK6 kinases are activated by abiotic $[11,15,17]$ and biotic stresses $[18,19]$. Low temperature, low humidity, hyperosmolarity, salt stress, touch, and wounding induced a rapid, transient activation of both Arabidopsis MPK4 (B group) and MPK6 without any significant change in amount of mRNA or protein level [11].

Compared to human MAP kinase cascades [20], plant MAP kinase pathways are more complex and only little information is available about their components. So far, only one complete MAP kinase cascade, from receptor to transcription factor, was identified in A. thaliana in response to biotic stress [18]. Potential components of MAP kinase cascade triggered by abiotic stress were described using two-hybrid system, yeast mutant complementation, and in-gel kinase assay. MAP3K8 is transcriptionally induced by salt stress, drought, cold, and wounding [21] and can interact with MKK1 and MPK4 to form potential MAP kinase module $[22,23]$. Recently, using high-throughput phosphorylation microarrays, 48 potential substrates of MPK3 and 39 of MPK6 were identified [24].

The signalling specificity via MAP kinases is an important feature to understand how a given signal is directed to a particular target. One of the ways to ensure specificity is the presence of scaffold proteins $[25,26]$ that form enzymatic complexes between the different elements in a given MAP kinase pathway. Only very few published data about plant scaffold proteins are available. Nevertheless, MAP kinase proteins themselves might play the role of scaffold proteins to ensure signal specificity [27]. Another feature for MAP kinase specificity is the presence of compatible docking domains, which ensure the affinity between all components of the same signalling pathway [28]. Surprisingly, some MAP kinase components appear to act as positive regulators for abiotic stress but negative regulators for biotic stress [4], as the overexpression of some MAP kinase genes enhances abiotic stress tolerance whereas the knock-out of other MAP kinases increases the plant resistance to pathogen.

Many MAP kinases are activated by more than one stimulus, enhancing the complexity of MAP kinase signalling networks. Regulation via modular and frequently cross-talking MAP kinase modules are a common scheme in their organization. MAP kinases can be regulated at transcriptional, translational, or post translational levels. Global transcriptional analysis of MAP kinase cascade components under stress conditions provides an overview of potential biological functions of MAP kinase genes whose mRNA levels change in response to stress. Using an original macroarray approach, we chose to analyze with a high sensitivity the transcript levels of MAP kinase genes. Expression levels of whole $M P K$ and $M K K$ gene families and of some candidate members of MAP3K and MAP4K gene families were analyzed under different osmotic and water stress conditions together with known stress marker genes.
Our results revealed specific patterns of MAP kinase gene expression upon abiotic stresses and functional MAP kinase modules may be suggested. Many of the noncharacterized MAP kinase genes showed a significant induction indicating a potential role of these kinases in stress adaptation. In addition to the gene expression analysis, the activity of some MAP kinases proteins was also investigated.

\section{Materials and Methods}

2.1. Plant Materials. A. thaliana cells, Columbia accession, were cultured in liquid medium as previously described [15] and subcultured after 5 days at density of $100 \mathrm{mg}$ fresh weight $/ \mathrm{mL}$. A. thaliana Columbia seeds were surfacesterilized in sodium hypochlorite $\left(12^{\circ}\right.$ chloride) for 5 minutes, rinsed 5-6 times in sterile water, dried and sowed on Petri plates in 0.5x MS medium [29], 1\% bacto-agar, and $0.5 \mathrm{~g} / \mathrm{L}$ MES. Seeds were then cold-stratified at $4^{\circ} \mathrm{C}$ for 24 hours and transferred to culture room at $22^{\circ} \mathrm{C}$ and light $\left(125 \mu \mathrm{M} \mathrm{m}^{-2} \mathrm{~s}^{-1}\right)$ on a 16 hours light/8 hours dark cycle. Plant organs were prepared from Arabidopsis plants cultured in soil for one month at $22^{\circ} \mathrm{C}$ under 16 hours photoperiod. Hydroponic plants were also used for the preparation of roots and rosette leaves. To obtain hydroponic plants, seeds were treated as above and sowed in $0.5 \mathrm{~mL}$ Eppendorf tubes containing MS solid medium, and half-cut to be adapted to custom-made polystyrene sheets as support. Polystyrene sheets with tubes were floated in opaque plastic tank containing autoclaved liquid culture medium [30] and then placed in culture box at short day ( 9 hours light, 15 hours dark), $22^{\circ} \mathrm{C}$ and $50 \%$ relative humidity. Culture medium was renewed twice a week to prevent contamination.

2.2. Stress Treatments. Osmotic stresses were applied to cells equilibrated for 4 hours in their culture medium containing $10 \mathrm{mM}$ MES-Tris, $\mathrm{pH}$ 6.2, and adjusted to $200 \mathrm{mOsm}$ with sucrose. After equilibration, medium was replaced by either the same volume of hypoosmotic medium, 20 mOsm of medium A composed of $10 \mathrm{mM}$ MES-Tris, $\mathrm{pH} 6.2,1 \mathrm{mM}$ $\mathrm{CaSO}_{4}, 10 \mathrm{mM}$ sucrose or isoosmotic medium, $200 \mathrm{mOsm}$ (medium A plus $180 \mathrm{mM}$ sorbitol), or hyperosmotic medium $500 \mathrm{mOsm}$ (medium A plus $480 \mathrm{mM}$ sorbitol). Cells were maintained in these media under gentle shaking and continuous light during all treatments. After treatments, cells were harvested by filtration, frozen in liquid nitrogen, and stored at $-80^{\circ} \mathrm{C}$ until use. Osmolarity was monitored using a freezing point osmometer (Roebling, Berlin, Germany). Dehydration and osmotic stress were applied to in vitro seedlings by transferring them onto Whatman paper at room temperature (dehydration stress) or onto liquid media containing $200 \mathrm{mM} \mathrm{NaCl}$ or $320 \mathrm{mM}$ mannitol for hyperosmotic stress treatments. Recovery treatments were performed by transferring stressed seedlings onto a normal growth medium. They were then harvested at different time points and stored at $-80^{\circ} \mathrm{C}$ until RNA extraction.

2.3. Preparation of DNA Macroarrays. When it was possible, primers were chosen in the $5^{\prime}$ - or $3^{\prime}$-nontranslated gene 
regions. The size of the amplified fragments ranged between 200 and $300 \mathrm{bp}$. Using specific primers (Table 1), 44 amplicons corresponding to the $20 \mathrm{MPK}, 10 \mathrm{MKK}, 12 \mathrm{MAP} 3 \mathrm{~K}$, and 2 MAP4K genes, were amplified by PCR from cDNA or genomic DNA and then cloned in Escherichia coli. PCR reactions were performed in $50 \mu \mathrm{L}$ using Eurobio Kit and PCR Express machine (PerkinElmer) with the following PCR program: 1 cycle of 1 minute 30 at $94^{\circ} \mathrm{C}$ for initial denaturing and 25 cycles of 45 seconds at $94^{\circ} \mathrm{C}$ (denaturing), 45 seconds at $55^{\circ} \mathrm{C}$ (annealing), 50 seconds at $72^{\circ} \mathrm{C}$ (elongation) followed by 7 minutes at $72^{\circ} \mathrm{C}$. Amplicon quality and specificity were verified in $1.2 \%$ agarose gel. Specific MAP kinase DNA fragments were cut out, purified from gel using QIAquick Gel Extraction kit (Qiagen, France) and cloned into pGEM$\mathrm{T}$ vectors (Promega). After denaturation with $0.4 \mathrm{M} \mathrm{NaOH}$, $30 \mu \mathrm{L}(280 \mathrm{ng})$ of each PCR product were spotted onto $7.5 \times$ $11 \mathrm{~cm}$ nylon membrane (Nytran, Schleicher \& Schuell) using the Dot Blot system (Fisher). The spotted membranes were then cooked at $80^{\circ} \mathrm{C}$ for 2 hours and conserved at room temperature until hybridization. To check the quantity of spotted PCR products, membranes were first hybridized with polynucleotide kinase (PNK) radiolabelled T7 primer (common to all inserts) and hybridization signals were evaluated. T7 primer radiolabelling was performed in $50 \mu \mathrm{L}$ containing $1 \mu \mathrm{L} 100 \mu \mathrm{M}$ T7 primer (200 pmol), $34 \mu \mathrm{L} \mathrm{H}_{2} \mathrm{O}, 5 \mu \mathrm{L} 10 \mathrm{X}$ PNK buffer, $5 \mu \mathrm{L}$ of PNK $(10 \mathrm{U} / \mu \mathrm{L})$, and $5 \mu \mathrm{L}\left[\gamma_{-}{ }^{33} \mathrm{P}\right]$-ATP $(3000 \mathrm{Ci} / \mathrm{mmol} ; 10 \mu \mathrm{Ci} / \mu \mathrm{L})$ and incubated at $37^{\circ} \mathrm{C}$ for 1 hour. Membranes were prehybridized with $10 \mathrm{~mL}$ Church buffer (0.5 M phosphate buffer, 7\% SDS, $1 \mathrm{mM}$ EDTA, $1 \%$ $\mathrm{BSA})$ at $65^{\circ} \mathrm{C}$ with gentle shaking overnight, washed twice in $50 \mathrm{~mL}$ SSARC $(600 \mathrm{mM} \mathrm{NaCl}, 60 \mathrm{mM}$ sodium citrate, $7.2 \%$ N-lauroyl sarcosine) at room temperature and twice at $4^{\circ} \mathrm{C}$. Membranes were hybridized with radiolabelled T7 primer in $50 \mathrm{~mL}$ SSARC at $4{ }^{\circ} \mathrm{C}$ overnight, washed twice 15 minutes in $50 \mathrm{~mL}$ precold SSARC at $4^{\circ} \mathrm{C}$, wrapped in Saran, exposed to phosphosensitive screen for 3-5 hours and scanned at $200 \mu \mathrm{m}$ using PhosphorImager (GE Healthcare). $25 \mu \mathrm{g}$ total RNA was incubated with $7.25 \mu \mathrm{g}$ oligo dT(1218) (Invitrogen, Cergy-Pontoise, France) in total volume of $21 \mu \mathrm{L}$, heated to $70^{\circ} \mathrm{C}$ for 10 minutes and then cooled on ice for $\geq 2$ minutes. Tubes were briefly centrifuged and the following components were added: $10 \mu \mathrm{l}$ of first strand buffer, $5 \mu \mathrm{l}$ DTT ( $100 \mathrm{mM}$ ), $5 \mu \mathrm{l}$ dNTPs ( $10 \mathrm{mM}$ each of dATP, dGTP, and dTTP), $5 \mu \mathrm{l}$ of $\left[\alpha{ }^{32} \mathrm{P}\right]$-dCTP $(10 \mu \mathrm{Ci} / \mu \mathrm{l}, 3000 \mathrm{Ci} / \mathrm{mol})$ and $2 \mu \mathrm{l}$ of PowerScript Reverse Transcriptase (Clontech, St Quentin-en-Yvelines, France). Reactions were incubated at $42^{\circ} \mathrm{C}$ for 1 hour, $2 \mu \mathrm{L}$ of cold dCTP were added and reaction was incubated further 1 hour at $42^{\circ} \mathrm{C}$. The synthesized labelled cDNA probes were purified using ProbeQuant G50 Micro Columns (GE Healthcare) following the manufacturer protocol. One $\mu \mathrm{L}$ of each reaction was taken before and after purification to calculate CPM (count per minute) using scintillation counter to determine the percentage of incorporation. Purified cDNA probes were denatured by adding $80 \mu \mathrm{L}$ of $1 \mathrm{X}$ STE buffer (0.5X final), $48 \mu \mathrm{L} 1 \mathrm{M} \mathrm{NaOH}(0.2 \mathrm{M}$ final), incubated at room temperature for 10 minutes and then neutralized by $48 \mu \mathrm{L}$ of $1 \mathrm{M} \mathrm{HCl}(0.2 \mathrm{M}$ final $)$ and $48 \mu \mathrm{L}$ of 20X SSC. Prehybridization was performed at $65^{\circ} \mathrm{C}$ for $\geq 3$ hours in $10 \mathrm{~mL}$ Church buffer [31] prewarmed to $65^{\circ} \mathrm{C}$.
Then, denatured cDNA probes were added at equal CPM levels and hybridization was carried out at $65^{\circ} \mathrm{C}$ overnight. Membranes were washed twice in 2X SSC, $0.1 \%$ SDS at room temperature for 30 minutes, and twice in 1X SSC, SDS $0.1 \%$ at $65^{\circ} \mathrm{C}$ for 20 minutes, then wrapped in Saran film and exposed to phosphor sensitive screens for 24-48 hours. Phosphor screens exposed to macroarray filters were scanned with PhosphorImager (GE Healthcare) at $200 \mu \mathrm{m}$ resolution. After image acquisition, the scanned images were analyzed using ImageQuant TL 2003 to quantify the radioactivity of each spot. Background corresponding to nonspecific hybridizations (water or empty spot intensity values) was subtracted from the signal intensity of each spot. The signal intensities of each spot from three independent experiments were averaged and normalized against the intensity of ACTIN2/8 or as a percentage of the total sum of all spots on the membrane. Genes were considered as induced/repressed when expression ratio (experimental/control) was $\geq 2.5$-fold.

2.4. Protein Extraction. Plant materials were ground in liquid nitrogen, homogenized at $4^{\circ} \mathrm{C}$ in extraction buffer $(100 \mathrm{mM}$ HEPES, pH 7.5, 5 mM EDTA, 5 mM EGTA, $10 \mathrm{mM}$ orthovanadate, $10 \mathrm{mM} \mathrm{NaF}, 60 \mathrm{mM}$ B-glycerophosphate, $10 \mathrm{mM}$ DTT, $1 \mathrm{mM}$ phenylmethylsulfonyl fluoride, $5 \mu \mathrm{g} / \mathrm{mL}$ leupeptin, and $5 \mu \mathrm{g} / \mathrm{mL}$ antipain) and centrifuged at $17.600 \times g$ at $4^{\circ} \mathrm{C}$. Soluble protein concentration was determined by the Bradford method with bovine serum albumin as standard [32].

2.5. Immunoprecipitation. Immunoprecipitation assays were performed with three polyclonal anti-MPK antibodies, which were raised against the $16 \mathrm{~N}$-terminal amino acids of Arabidopsis MPK3, MPK4, and MPK6 [15]. Protein extracts ( $400 \mu \mathrm{g}$ for MPK4 antibody and $200 \mu \mathrm{g}$ for the two others) were incubated in $400 \mu \mathrm{L}$ with $30 \mu \mathrm{g}$ anti-MPK4, $10 \mu \mathrm{g}$ anti-MPK3, or $10 \mu \mathrm{g}$ anti-MPK6 in immunoprecipitation buffer at $4^{\circ} \mathrm{C}$ for 3 hours as previously described [15]. Then $30 \mu \mathrm{L}$ of $50 \%$ protein A-Sepharose CL4B (Sigma) was added and incubation continued for one additional hour. The immunoprecipitate was washed several times and resuspended in SDS-PAGE sample buffer before being electrophoresed in SDS-PAGE embedded with MBP for ingel kinase assay [15].

2.6. In-Gel Kinase Assay. Protein extracts $(20 \mu \mathrm{g})$ were electrophoresed in $10 \%$ SDS-PAGE embedded with $0.2 \mathrm{mg} / \mathrm{mL}$ myelin basic protein (MBP) as substrate for the kinases. The gels were then treated for washing and renaturing steps as described by Zhang et al. [33]. For the activity, the gels were pre-incubated for 30 minutes at room temperature in kinase activity buffer (40 mM HEPES pH 7.5, 2 mM DTT, $20 \mathrm{mM} \mathrm{MgCl}_{2}, 1 \mathrm{mM}$ EGTA, $0.1 \mathrm{mM}$ orthovanadate) then 1 hour in $8 \mathrm{~mL}$ of the same buffer supplemented with $25 \mathrm{mM}$ cold ATP and $2.9 \mathrm{MBq}\left[{ }^{33} \mathrm{P}\right]$ ATP per gel. The gels were then washed extensively in 5\% TCA (w/v) and 1\% disodium pyrophosphate $(\mathrm{w} / \mathrm{v})$ solution and under vacuum dried. The protein kinase activity was revealed on the dried gels by Storm imaging system (GE Healthcare). 
TABLE 1: Oligonucleotides used to amplify the MAP kinase fragments from cDNA or genomic DNA. F: forward; R: reverse.

\begin{tabular}{|c|c|c|c|}
\hline Gene name & Locus & \multicolumn{2}{|c|}{ Primer sequences $\left(5^{\prime}-3^{\prime}\right)$} \\
\hline \multicolumn{4}{|c|}{ MPK gene family } \\
\hline MPK1 & At1g10210 & F: GCCAAATCTCTCTCACTTCCACAGGT & R: CCGTAAGCTCCACGACCAATAGGC \\
\hline MPK2 & Atlg59580 & F: CCGTAAGCTCCACGACCAATAGGC & R: CACACCGTACGCGCCTCG \\
\hline MPK3 & At3g 45640 & F: ACCTTGCTAAATTGCACGACCCGA & R: AGCCATTCGGATGGTTATTGGGT \\
\hline MPK4 & At4g01370 & F: TTGTTGTGAGGAATTTTGCTCCG & R: GCTACСTCСТCTCCAGTCTCTGAG \\
\hline MPK5 & At4g11330 & F: CTCGAATCTGTGAAGTTCAATCCTCTGC & R: GAAGAAACAGAACACTATCTAAGACATCCTG \\
\hline MPK6 & At2g43790 & F: GAGATGAAGATGAGATAAGGGTT & R: GGTGGGCTATCATAACATAACTATTTC \\
\hline MPK7 & At2g18170 & F: GCCCGGTGCTTTGATCTCGTCTG & R: GGCTAGCAAGTGGGGCAATGGC \\
\hline MPK8 & Atlg18150 & F: GTTTTCTGGTGAAAAGAAATTG & R: GCAAAGTGAATACTGAATAG \\
\hline MPK9 & At3g18040 & F: TTCCTCTACCAGCTTCTTCGT & R: TACCATCTTGTAGCAACATAGTCAG \\
\hline MPK10 & At3g59790 & F: ATGGAGCCAACTAACGATGCTG & R: CAAACGATGCCACAAGCACCTC \\
\hline MPK11 & Atlg01560 & F: GTCAATAGAGAAACCATTCTTCGGTGATG & R: GGCAATGACATTGTCATGATCCATATGCT \\
\hline MPK12 & At2g46070 & F: CCTTCTTCTTGGTTTCTCTCGTTCTCGG & R: CCGCAGCACAGACAATACCG \\
\hline MPK13 & Atlg07880 & F: GATGCTAGTTTTCGATCCTTC & R: CTTGAAGTGTAAAGACTCTCTCCAGAC \\
\hline MPK14 & At4g36450 & F: GGATCTCCAGTTCATAGATAACCA & R: CTCCAAACTACTGACCGGAACA \\
\hline MPK15 & Atlg73670 & F: CGAGTTCCAGCATCCAAGAATG & R: CAATGTTGGTTTTAGATTGTACACC \\
\hline MPK16 & At5g19010 & F: AGTGTTACGCTATAACAACTGC & R: TTAATACCAGCGACTCATTG \\
\hline MPK17 & At2g01450 & F: GTTGGCAAAGGAAGCTACGG & R: GATGATGCTGAGGAGTGAGG \\
\hline MPK18 & Atlg53510 & F: GAAGTTATTGGTAAAGGAAGCTATGGAGTT & R: ATCTGATTCCATGAGCTCAAACACAACA \\
\hline MPK19 & At3g14720 & F: ACAGTACTCCCTCCACAGACCGTA & R: CTAAGACATGCCATACCCAACAGC \\
\hline MPK20 & At2g42880 & F: GATATGCACCAGATGTAGCC & R: GCCCAGCTTAGGTGGAGAAC \\
\hline \multicolumn{4}{|c|}{ MKK gene family } \\
\hline MKK1 & At4g26070 & F: AAGATGTTTGAAGATTCGGA & R: ATCCACCACTAGCAGAGAAA \\
\hline MKK2 & At4g29810 & F: AAATACGACTACTCGGGGAT & R: TTTTAAATAAACACTCTCATGTACC \\
\hline MKK3 & At5g 40440 & F: GATGGAGTCCAAGCAGAAGG & R: TCCGGCACTTTTTATGAACC \\
\hline MKK4 & Atlg51660 & F: TCGTCCTCTGTCCTCGTCTT & R: GGGGATACATGCACCATCAT \\
\hline MKK5 & At3g21220 & F: TCCATAAGTTTTGCATACCC & R: GCAAATCCAGCTAAAATCAC \\
\hline MKK6 & At5g56580 & F: TTTGATTTGGCCTTAATGAAATG & R: CTTGTTGGCACTCTGGAACC \\
\hline MKK7 & At1g18350 & F: ACCCTTTTCTCCGTGAAAGT & R: TTCCTCTGTTTCTGTCGATTG \\
\hline MKK 8 & At3g06230 & F: TGGACTGCTGTTTACGCAAG & R: GTGGAGACCCTACATCTCGC \\
\hline MKK9 & Atlg73500 & F: CCCAAAACTTATGTACACGATTGA & R: CTTGCTCATCCTTTTCTCCG \\
\hline MKK 10 & Atlg32320 & F: GTGGAAGAGCTTCTTCGTCA & R: CTGAACTCGAATCAAACCAAA \\
\hline \multicolumn{4}{|c|}{ MAP3K gene family } \\
\hline$M A P 3 K 1$ & At1g09000 & F: TCACCAGGAAAATGACTTGC & R: CTAGCAATTTGTAGCGCACT \\
\hline$M A P 3 K 2$ & Atlg54960 & F: GCATCTCCAGGCAAATGATC & R: GGCTTAACACTCAATATGCA \\
\hline MAP3K3 & At1g53570 & F: CCCCTAGTTTTGGCCTTCTC & R: AGGTTGAAAACAAATGGTTGAA \\
\hline$M A P 3 K 4$ & At1g63700 & F: CCTCTTCATCCTCGAGCTGGA & R: GCGATCCAGGGCTAACCGTA \\
\hline MAP3K5 & At5g66850 & F: GCAGCTCGAGAGGTTAACCAA & R: GCTTCTTCTATCGATTCAACATTG \\
\hline MAР3К6 & At3g07980 & F: GTGAGTGTACATTTATTCCC & R: GATCACATCACGTCCACATTAA \\
\hline MAP3K7 & At3g13530 & F: GTCCACCAAAACGATAATATCCC & R: GAAGGCTAGCAAGAGCAGTATA \\
\hline МАРЗК8 & At4g08500 & F: ATACACCCAAAAACCCCAAG & R: AGCAGGCATAACCCGAAGAT \\
\hline MAP3К9 & At4g08480 & F: CAACAACCAACCAATGAATGA & R: CCTCCATAGGTGAAGCCTCT \\
\hline MAP3K10 & At4g08470 & F: CTGTACGGTGTACGGAGTCG & R: TGCAATAGTATGGCGAAAACC \\
\hline MAP3K11 & At4g12020 & F: CCCGGTTATGTTTCCTTCAG & R: CAGTACACCCAAGGCTCCAT \\
\hline MAP3K12 & At3g06030 & F: GAGAATCTGCGACACGCTGGTGC & R: CTATGAACCGTTGAAGAACT \\
\hline \multicolumn{4}{|c|}{ MAP4K gene family } \\
\hline MAP4K1 & At1g53165 & F: CTCGGTCCGAAGAGATTATGTGC & R: AAGCTGAGCCGTTACAATCTCCG \\
\hline MAP4K2 & At3g 15220 & F: CCTGAGACAACCTACAGAGAT & R: GCCACACCCTTGATTATACAC \\
\hline
\end{tabular}




\section{Results}

3.1. Macroarray Design and Data Analysis. Completion of the Arabidopsis genome has made possible to define the full content of MAP kinase family members in a single plant species, disclosing more than a hundred genes clustered into several families. To search for putative components of MAP kinase water stress signalling, macroarrays were designed for expression profiling of the whole $M P K$ and $M K K$ genes, as well as selected members of the MAP3K and MAP4K families. MPK (20 genes) and MKK (10 genes) families display very close sequence similarity among their members, but the MAP3K family is represented by many more members with greater variety in primary structures and domain compositions. For the MAP3K family, the 12 members of the subgroup whose kinase domains have significant similarity to typical MAP3K were selected. Since the sequences of the different kinases inside each group are very close, full length sequences could not be used and 200-300 bp fragments were cloned, allowing both strong hybridization signal and high specificity.

To optimize the sensitivity of the macroarrays, manual spotting was preferred, allowing to deposit a large volume $(30 \mu \mathrm{L})$ by spot, corresponding to about $280 \mathrm{ng}$ of PCR product. The homogeneity of the spotting was verified by oligonucleotide hybridization using T7 primer (data not shown).

To standardize the results, the ACTIN2/ACTIN8 genes have been used, due to their demonstrated stable expression upon various environmental stresses. Thus, relative transcript level of each MAP kinase or marker gene standardized with the ACTIN 2/8 transcript level is presented in the context of water stress experiments. In the case of the expression profiling of the genes in Arabidopsis organs, ACTIN 2/8 expression displayed a maximum of 4 -fold variation, ranging from 4.2 (floral buds) to 16.5 (roots) when expressed in the percentage of the expression level sum for all studied genes. Relative transcript level of each MAP kinase standardized with the expression level of the total spotted genes will be presented in Section 3.2 concerning organs.

3.2. Relative Expression Profile of the MAPK Genes in Arabidopsis Organs. The relative transcript level of the 44 studied Arabidopsis MAP kinase genes in different organs is presented in Figure 1. In the growth conditions used, quite similar expression profiles are observed from one organ to another and MPK3, MKK9, and MAP3K3 transcript levels were the highest in each gene family, respectively. Some other kinase genes also displayed clear transcriptional activity in most organs, in the absence of stress: the MPK: $6,8,16,17$, 19, and 20, the MKK: 1, 2, 4, 5, as well as the MAP3K: 5, 6, and 7. It is also interesting that differences can be noticed in the expression level of some genes, depending of the Arabidopsis organ. For example, a higher expression of MPK17, MPK20, and MAP3K6 is observed in roots in comparison with other tested organs.

3.3. Protein Kinase Activity of MPK3, MPK4, and MPK6 in Arabidopsis Organs. The three MPK3, MPK4, and MPK6 kinases were previously shown to be activated very early upon osmotic stresses in cell suspensions [15,34]. Therefore, it was interesting to measure their corresponding activity in different Arabidopsis organs. The organ protein extracts were submitted to SDS-PAGE followed by an in-gel kinase assay using MBP as a substrate (Figure 2(a)). Three active kinase proteins were observed in most organs, with apparent molecular weights around 44,39, and $37 \mathrm{kDa}$. These values correspond to the apparent molecular weights reported for MPK6, MPK3, and MPK4, respectively. To confirm the identification of the active proteins detected in the organs, specific polyclonal antibodies directed against MPK3, MPK4, and MPK6 were used to immunoprecipitate each kinase from protein extracts of rosette leaves and roots (Figure 2(b)). The result clearly indicates the identification of MPK6, MPK3, and MPK4 as the active proteins corresponding to 44,39 , and $37 \mathrm{kDa}$ in rosette leaves and roots and strongly suggests that the same active kinases are detected in the other organs, with the exception of siliques in which the activity of MPK 3 could not be detected (Figure 2(a)).

3.4. Relative Expression Profile of the MAP Kinase Genes upon Water Stress. Expression profiles of the 44 kinase genes as well as marker genes were investigated in different conditions of abiotic stresses: hypoosmolarity, hyperosmolarity, salinity, dehydration, as well as recovery after hyperosmotic or salt stresses.

Cell suspensions were submitted to hypo- or hyperosmotic stress (Table 2). Significant variations of the marker genes were observed, validating the stress protocol used. Classical markers of hyperosmolarity were induced, RAB18 as early as 30 minutes and $R D 29 A$ at 1 hour of hyperosmotic stress. It is interesting to note that these two genes were also induced, although less strongly, from 30 minutes of hypoosmotic stress and they thus appear as general markers of osmotic variations. The key genes of the proline pathway behaved as expected with the inductions of P5CS1 from 1 hour of hyperosmotic stress and ProDH from 30 minutes of hypoosmotic stress. For the kinase genes, rapid and transient induction of MPK20 by hypoosmolarity was observed, with similar kinetics than ProDH (Table 2). MPK7, MPK14, and MPK17 as well as MKK7 were transiently induced from 3 hours of hyperosmolarity.

Plantlets were also submitted to dehydration, mannitol, or salt stress (Table 3). RD29A and RAB18 were induced in each case as expected. On the contrary, P5CS1 was not induced by dehydration, but only by mannitol or salt stress in the tested conditions. For ProDH, induction was observed in the case of a return to basal conditions after mannitol or salt stress (Table 3 ), coherently with the previously noticed induction by hypoosmolarity (Table 2 ).

Genes belonging to each MAP kinase family were induced in each case in response to dehydration, hyperosmolarity, or salinity stresses. The increase of transcript levels by hyperosmolarity in cell suspensions was confirmed in young plantlets, namely MPK7, MPK14, MPK17, and $M K K 7$, but more inductions by hyperosmolarity could be detected in plants, with MPK9, MPK10, MPK11, MPK18, 

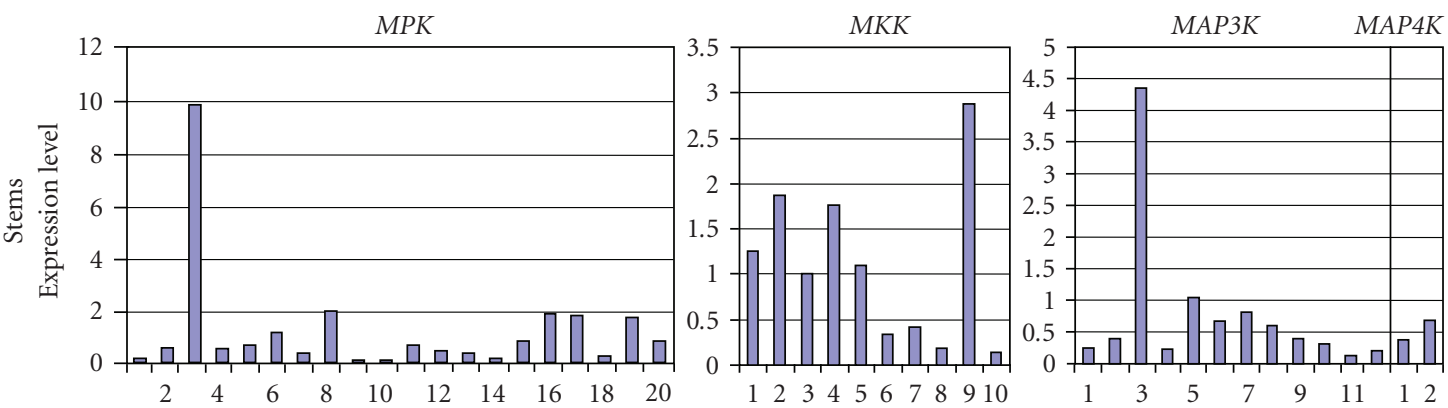

(a)
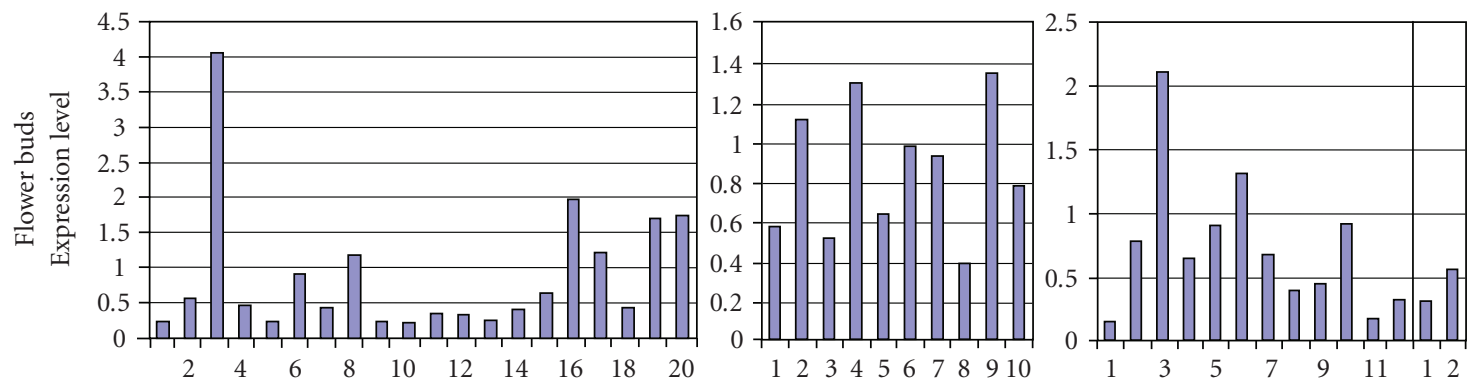

(b)
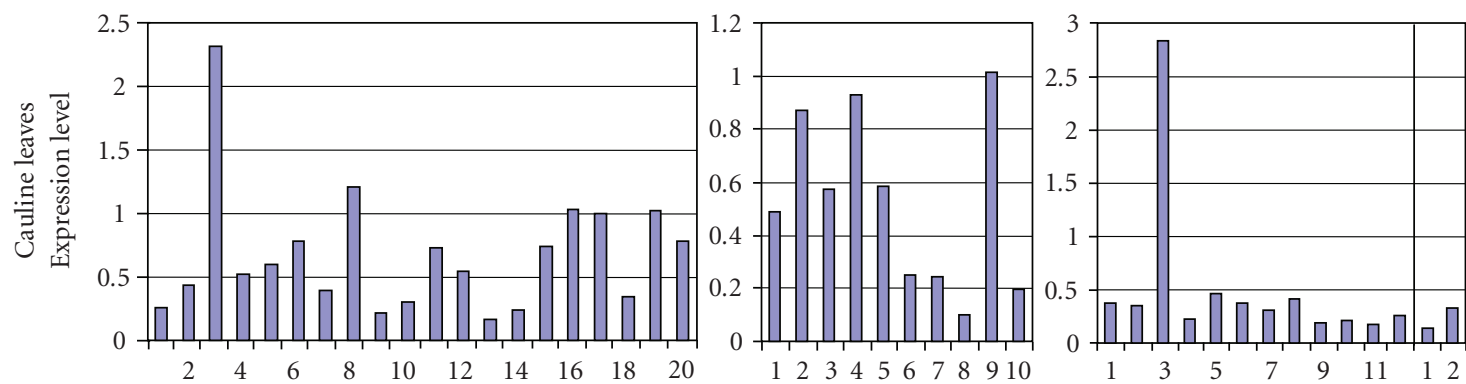

(c)
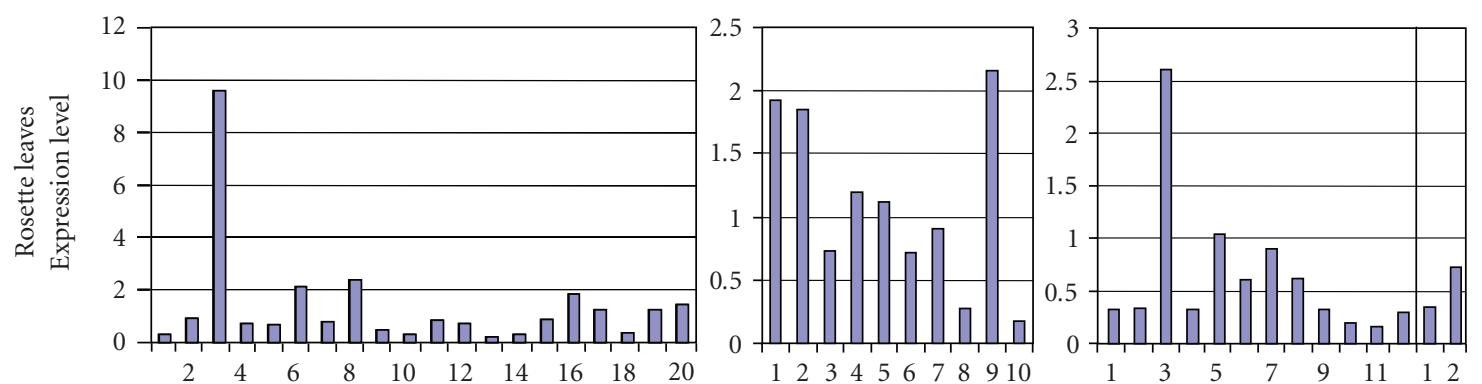

(d)
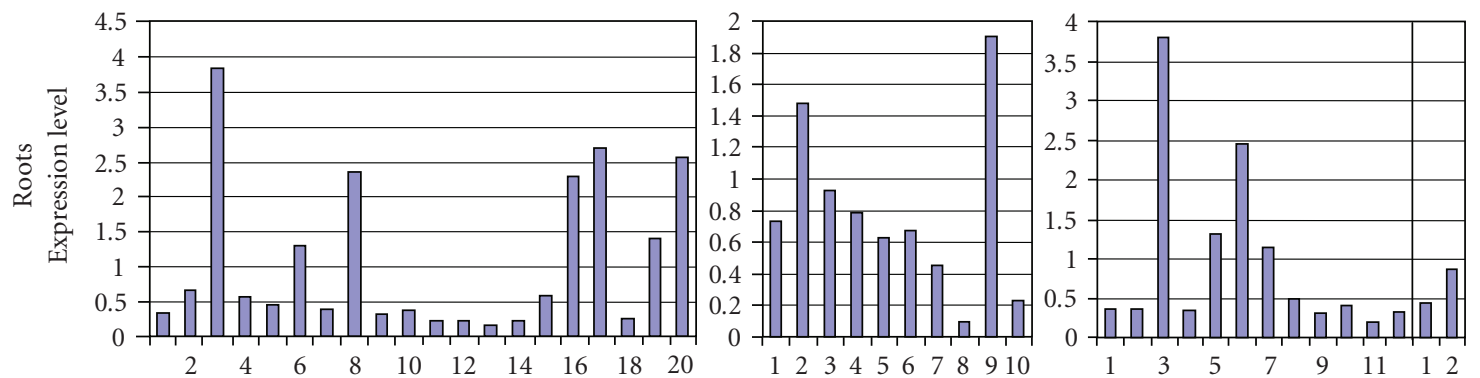

(e)

Figure 1: Relative expression profiles of the MAP kinase genes in different organs of $A$. thaliana. The transcript levels of the 20 MPK, 10 $M K K$, the MAP3K 1 to 12 , and the MAP4K 1 and 2 are represented. The expression level is represented as a percentage of the sum of the values for all genes. 


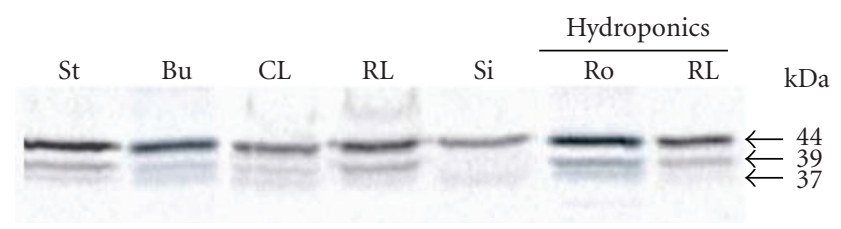

(a)
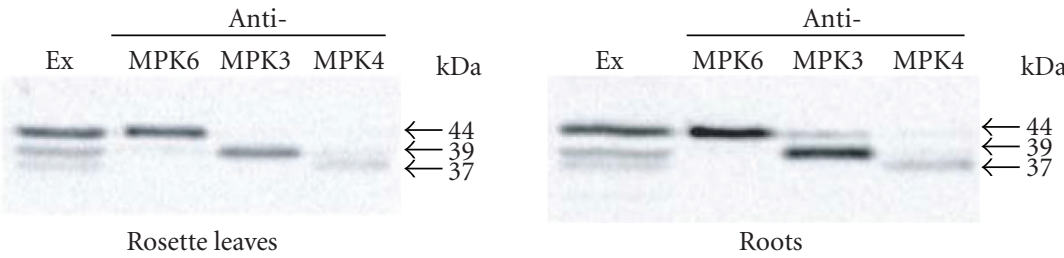

(b)

Figure 2: Protein kinase activity assay in different organs of $A$. thaliana. Organs were prepared from plants grown in soil ((a), left part) or in hydroponics ((a), right part: "Hydroponics" and (b)). Proteins present in crude extracts (a) or immunoprecipitates (b) were analyzed by in-gel kinase assay using MBP as a substrate. In (b), specific antibodies against MPK6, MPK3, and MPK4 were used for immunoprecipitation and a crude extract (Ex) was compared. St: stems; Bu: flower buds; CL: cauline leaves; RL: rosette leaves; Si: siliques; Ro: roots.

TABLE 2: Differential expression of MAP kinase genes under osmotic stresses in A. thaliana cell suspensions. The table presents the variations of transcript levels during the treatment kinetics, compared with the corresponding control values in the absence of stress. Among the 44 tested kinase genes, only the genes displaying a transcript level variation are indicated. The variations of markers genes are indicated at the bottom of the table. 0: Variation less than 2.5 fold; + : increase; $(n): n$-fold increase.

\begin{tabular}{|c|c|c|c|c|c|c|c|c|}
\hline \multirow{3}{*}{ Gene } & \multicolumn{8}{|c|}{ Cell treatments } \\
\hline & \multicolumn{4}{|c|}{ Hypoosmotic stress } & \multicolumn{4}{|c|}{ Hyperosmotic stress } \\
\hline & $30 \mathrm{~min}$ & $1 \mathrm{~h}$ & $3 \mathrm{~h}$ & $6 \mathrm{~h}$ & $30 \mathrm{~min}$ & $1 \mathrm{~h}$ & $3 \mathrm{~h}$ & $6 \mathrm{~h}$ \\
\hline \multicolumn{9}{|c|}{ MPK genes } \\
\hline MPK7 & 0 & 0 & 0 & 0 & 0 & 0 & $+(2.6)$ & 0 \\
\hline MPK14 & 0 & 0 & 0 & 0 & 0 & 0 & $+(3.1)$ & 0 \\
\hline MPK17 & 0 & 0 & 0 & 0 & 0 & 0 & $+(2.9)$ & 0 \\
\hline MPK20 & $+(3.0)$ & 0 & 0 & 0 & 0 & 0 & 0 & 0 \\
\hline \multicolumn{9}{|c|}{ MKK genes } \\
\hline MKK7 & 0 & 0 & 0 & 0 & 0 & 0 & $+(2.6)$ & 0 \\
\hline \multicolumn{9}{|c|}{ Marker genes } \\
\hline$R D 29 A$ & $+(4.4)$ & $+(3.2)$ & 0 & 0 & 0 & $+(5.1)$ & $+(8.6)$ & $+(3.3)$ \\
\hline$R A B 18$ & $+(2.6)$ & $+(3.4)$ & 0 & 0 & $+(2.9)$ & $+(14.8)$ & $+(151.2)$ & $+(30.3)$ \\
\hline P5CS1 & 0 & 0 & 0 & 0 & 0 & $+(3.2)$ & $+(4.9)$ & 0 \\
\hline ProDH & $+(5.1)$ & 0 & 0 & 0 & 0 & 0 & 0 & 0 \\
\hline
\end{tabular}

as well as MKK3, MKK4, MKK6, MKK9, and MAP3K3, MAP3K5, MAP3K6, MAP3K7, MAP3K9. Surprisingly, no specific induction by salinity was observed and most genes induced by mannitol were also induced by $\mathrm{NaCl}$ treatment with the exception of MPK14 and MAP3K9. A set of genes was also induced by dehydration, some of them shared by salinity and/or hyperosmolarity, the others specific for dehydration: $M P K 2, M P K 3, M P K 4, M P K 5, M P K 12$, and MAP3K4 (Table 3).

\section{Discussion}

Since the completion of the Arabidopsis genome sequencing project, about one hundred of MAP kinase genes have been identified, annotated and classified into four families [1].
So far, only very few of the identified Arabidopsis MAP kinases were studied at biochemical levels in response to biotic or abiotic stresses, but the majority of them need to be functionally characterized. One of the early tasks to assign potential functions to genes is their expression analysis in order to determine where, when, and how each gene is switched on or off. The basic assumption underlying this approach is that genes with similar expression patterns are likely to be functionally related [35]. In this way, genes without previous functional assignments can be given a putative role in the biological process based on the expression profile. Moreover, for genes known to be functional and in cascades hieratically related (e.g., MAP kinases), this approach seems to be of a particular interest, as it allows to have global insight to the coregulated genes, 
TABLE 3: Differential expression of MAP kinase genes under different stress and recovery conditions in A. thaliana plantlets. The table presents the variations of transcript levels during the treatment kinetics, compared with the corresponding control values in the absence of stress. Among the 44 tested kinase genes, only the genes displaying a transcript level variation are indicated. The variations of markers genes are indicated at the bottom of the table. 0 : Variation less than 2.5 -fold; $+:$ increase; $(n): n$-fold increase.

\begin{tabular}{|c|c|c|c|c|c|c|c|c|c|c|c|}
\hline \multirow{4}{*}{ Gene } & \multicolumn{11}{|c|}{ Plantlet treatments } \\
\hline & \multicolumn{3}{|c|}{ Dehydration } & \multicolumn{4}{|c|}{ Mannitol } & \multicolumn{4}{|c|}{$\mathrm{NaCl}$} \\
\hline & \multirow[b]{2}{*}{$1 \mathrm{~h}$} & \multirow[b]{2}{*}{$3 \mathrm{~h}$} & \multirow[b]{2}{*}{$6 \mathrm{~h}$} & \multicolumn{2}{|c|}{ Stress } & \multicolumn{2}{|c|}{ Recovery } & \multicolumn{2}{|c|}{ Stress } & \multicolumn{2}{|c|}{ Recovery } \\
\hline & & & & $3 \mathrm{~h}$ & $24 \mathrm{~h}$ & $1 \mathrm{~h} 30$ & $5 \mathrm{~h}$ & $3 \mathrm{~h}$ & $24 \mathrm{~h}$ & $1 \mathrm{~h} 30$ & $5 \mathrm{~h}$ \\
\hline \multicolumn{12}{|c|}{ MPK genes } \\
\hline MPK2 & $+(2.6)$ & 0 & $+(4.0)$ & 0 & 0 & 0 & 0 & 0 & 0 & 0 & 0 \\
\hline$M P K 3$ & $+(3.1)$ & $+(5.0)$ & $+(5.1)$ & 0 & 0 & $+(5.5)$ & 0 & 0 & 0 & $+(4.6)$ & 0 \\
\hline MPK4 & $+(2.6)$ & 0 & $+(5.8)$ & 0 & 0 & 0 & 0 & 0 & 0 & 0 & 0 \\
\hline MPK5 & $+(3.1)$ & $+(3.0)$ & $+(3.5)$ & 0 & 0 & $+(3.4)$ & 0 & 0 & 0 & $+(2.9)$ & $+(3.9)$ \\
\hline MPK7 & 0 & 0 & 0 & $+(3.0)$ & $+(8.5)$ & 0 & 0 & $+(3.0)$ & $+(6.0)$ & 0 & $+(2.9)$ \\
\hline MPK9 & 0 & 0 & $+(4.6)$ & $+(2.8)$ & $+(8.8)$ & $+(5.7)$ & 0 & 0 & $+(4.2)$ & $+(5.1)$ & 0 \\
\hline MPK 10 & 0 & 0 & 0 & 0 & $+(30.6)$ & $+(2.9)$ & 0 & 0 & $+(20.7)$ & $+(5.3)$ & $+(2.7)$ \\
\hline MPK11 & $+(4.6)$ & $+(4.8)$ & $+(10.2)$ & 0 & $+(4.7)$ & $+(4.0)$ & 0 & 0 & $+(4.3)$ & 0 & 0 \\
\hline MPK 12 & 0 & 0 & $+(2.9)$ & 0 & 0 & $+(3.1)$ & 0 & 0 & 0 & 0 & 0 \\
\hline MPK14 & 0 & 0 & $+(2.6)$ & 0 & $+(2.7)$ & $+(4.4)$ & 0 & 0 & 0 & $+(8.3)$ & $+(5.7)$ \\
\hline MPK17 & $+(2.9)$ & $+(3.0)$ & $+(6.2)$ & $+(4.5)$ & $+(2.6)$ & $+(6.7)$ & 0 & 0 & $+(2.9)$ & $+(4.3)$ & $+(4.0)$ \\
\hline MPK 18 & 0 & $+(2.5)$ & $+(6.1)$ & $+(2.5)$ & $+(3.5)$ & 0 & 0 & 0 & $+(2.5)$ & 0 & 0 \\
\hline МРК20 & 0 & 0 & 0 & 0 & 0 & $+(3.3)$ & 0 & 0 & 0 & 0 & $+(2.9)$ \\
\hline \multicolumn{12}{|c|}{ MKK genes } \\
\hline MKK3 & 0 & 0 & 0 & 0 & $+(6.0)$ & 0 & 0 & $+(4.5)$ & $+(6.5)$ & 0 & 0 \\
\hline$M K K 4$ & 0 & 0 & 0 & $+(2.9)$ & $+(3.3)$ & $+(4.5)$ & 0 & $+(3.9)$ & $+(3.6)$ & 0 & $+(2.5)$ \\
\hline MKK6 & 0 & 0 & 0 & $+(4.3)$ & 0 & $+(2.9)$ & 0 & $+(3.1)$ & 0 & 0 & 0 \\
\hline MKK7 & 0 & 0 & 0 & $+(3.9)$ & 0 & 0 & 0 & $+(3.4)$ & 0 & 0 & 0 \\
\hline MKK9 & $+(3.2)$ & 0 & $+(3.6)$ & $+(4.0)$ & 0 & 0 & 0 & $+(3.5)$ & $+(3.2)$ & 0 & 0 \\
\hline \multicolumn{12}{|c|}{ MAP3K genes } \\
\hline$M A P 3 K 3$ & 0 & 0 & 0 & $+(3.2)$ & 0 & $+(2.5)$ & 0 & $+(4.5)$ & $+(3.0)$ & 0 & 0 \\
\hline MAP3K4 & 0 & 0 & $+(3.9)$ & 0 & 0 & $+(4.5)$ & 0 & 0 & 0 & 0 & $+(2.5)$ \\
\hline MAP3K5 & 0 & 0 & 0 & $+(2.8)$ & $+(3.1)$ & 0 & 0 & $+(2.9)$ & $+(3.0)$ & 0 & $+(4.7)$ \\
\hline МАРЗК6 & 0 & 0 & $+(2.9)$ & $+(5.6)$ & $+(2.8)$ & $+(3.3)$ & 0 & 0 & $+(2.7)$ & 0 & 0 \\
\hline MAP3K7 & 0 & 0 & 0 & 0 & $+(3.1)$ & $+(3.5)$ & 0 & 0 & $+(3.4)$ & $+(3.1)$ & $+(2.7)$ \\
\hline МАРЗК9 & 0 & 0 & $+(3.4)$ & $+(3.3)$ & $+(2.8)$ & $+(7.6)$ & 0 & 0 & 0 & $+(9.6)$ & 0 \\
\hline \multicolumn{12}{|c|}{ MAP4K genes } \\
\hline MAP4K2 & 0 & 0 & 0 & 0 & $+(4.1)$ & 0 & 0 & 0 & $+(4.0)$ & 0 & 0 \\
\hline \multicolumn{12}{|c|}{ Marker genes } \\
\hline$R D 29 A$ & $+(5.3)$ & $+(12.5)$ & $+(11.3)$ & $+(13.4)$ & $+(6.2)$ & 0 & 0 & $+(11.4)$ & $+(3.8)$ & $+(3.8)$ & 0 \\
\hline$R A B 18$ & $+(2.9)$ & $+(2.9)$ & $+(5.0)$ & 11.6 & 0 & $+(10.2)$ & 0 & $+(11.5)$ & $+(4.2)$ & $+(7.2)$ & $+(5.0)$ \\
\hline P5CS1 & 0 & 0 & 0 & $+(19.3)$ & $+(2.4)$ & $+(3.8)$ & 0 & $+(17.9)$ & $+(6.3)$ & $+(8.0)$ & $+(4.1)$ \\
\hline ProDH & 0 & 0 & 0 & 0 & 0 & $+(6.3)$ & 0 & 0 & 0 & $+(6.2)$ & $+(2.7)$ \\
\hline
\end{tabular}

suggesting that they may be involved in the same signalling pathway.

Based on this idea, a macroarray approach wasdeveloped in this study to measure MAP kinase expression levels in different Arabidopsis organs without any stress treatment, and also to monitor the impact of some environmental stresses (osmotic, salt, and dehydration) on the accumulation of MAP kinase transcripts both in Arabidopsis cell cultures and seedlings. A miniscale macroarray that contained an important number of MAP kinase genes (44 genes) belonging to the four identified MAP kinase families was constructed here. The choice of macroarray system using short DNA fragments is based on its high sensitivity and ability to distinguish between hybridization signals corresponding to closely related genes. The validity of this approach has been previously demonstrated for many other gene families in Saccharomyces cerevisiae or plants [5, 36-39]. The reliability of this method was ensured by a careful evaluation of the specificity of each amplicon, based on sequence comparison and BLAST analysis. The main criteria in designing the MAP kinase amplicons was that they should be as long and specific as possible (200-300 bp), while showing minimum 
homology to each other or to any other sequences in the Arabidopsis genome. The obtained data were averaged from three independent experiments and normalized using Actin value or the sum of the values for all spots on the membrane.

To evaluate the validity of expression profiling under stress treatment using DNA macroarray, we analyzed by real time RT-PCR (data not shown), the expression of some selected stress-inducible MAP kinase genes (e.g., MPK3, MPK18, MPK20 and MAP3K6). The results obtained by the two methods were in good agreement.

The MAP kinase gene expression profiles in five Arabidopsis organs, namely stems, flower buds, cauline leaves, rosette leaves, and roots, have shown that MAP kinase genes are generally not preferentially expressed in a part of the plant. The transcript levels of MPK3, MKK9, and MAP3K3, most highly expressed in each family, are detected in all tested organs. Nevertheless, some of them seem to be more expressed in certain organs than in others. Interestingly, MPK17, MPK20, and MAP3K6 are more strongly expressed in roots. Some Arabidopsis MAP kinase orthologous genes in other plants display a distinct localization in comparative organs. For example, the MPK3 ortholog in poplar, PtMPK31 (A group), displays a preferential expression profile in roots, and PtMPK17 (D group) is preferentially expressed in roots and leaves [40]. In rice, OsMPK4 has been shown to be more expressed in mature than in young leaves [3].

On the other hand, many MAP kinase genes of each family, namely MPK1, MPK9, MPK10, MPK13, MPK14, MPK18, MKK8, MKK10, as well as MAP3K1, MAP3K2, $M A P 3 K 11$, and MAP3K12 showed a very low expression level in the studied organs. From the 12 MAP3K studied genes, we found that MAP $3 K 3$ is highly expressed in the five Arabidopsis organs and MAP3K6 transcripts are relatively abundant in flower buds and roots. MAP kinase genes in $D$ group appear to be expressed at a relatively high level in the five tested organs, except MPK18 for which expression is hardly detectable.

No significant expression was observed for MKK8 and MKK10 in any organ or stress condition tested here. Indeed, MKK10 does not contain the phosphorylation site (S/TxxxxxS/T) specific to $M K K$ members [1] and no ortholog was found for $M K K 8$ in any other sequenced plant genome so far. This may reinforce the hypothesis emitted by Hamel [41] that MKK8 and MKK10 may be nonfunctional and the number of $M K K$ genes in Arabidopsis genome is eight instead of ten.

On the other hand, the accordance between the localization of kinase activity and mRNA transcript profiles was investigated in plant organs using MBP as phosphorylable substrate. Although MBP is a favorite substrate for MPK family members, only three bands were observed in activity gel assay. This may be due to problems related to protein denaturation/renaturation, or simply because these three MPK proteins were the only temporarily and spatially activated MAP kinases at this experimental time point.

Using specific anti-MPK antibodies, the identity and ubiquity of these proteins have been confirmed and shown to be MPK3, MPK4, and MPK6, present and active in all studied organs (except MPK3 in siliques) (Figure 2). It has been previously reported that these proteins are involved in multiple biotic and abiotic stress responses $[11,15,17,18,34$, 42-44]. Coherently with the detection of MPK3, MPK4, and MPK6 activities in different Arabidopsis organs (Figure 2), the three kinases were previously shown active at a basal level in the absence of stress, in cell suspensions [15] and plantlets [34]. Their activities shown here in Arabidopsis organs suggest that these three protein kinases may play roles in the developmental processes in the absence of stress too. It is worthy of note that MPK6 protein was activated in response to osmotic stress, but its mRNA transcript level was unchanged, suggesting that post-transcriptional mechanisms is required for MPK6 function. This is in agreement with previously reported results [11].

In both cell cultures and seedlings, the induction profiles of MAP kinase genes in response to water stresses were comparable to those of stress marker genes (RD29A, DREB2A, $P 5 C S 1$, and $P r o D H)$, although the induction factor was generally higher for these stress marker genes, indicating the reliability of the macroarray technique for this MAP kinase expression profiling study. The gene expression responses are dependent on the duration, the intensity, and the type of stress. A previous transcriptional profiling in response to abiotic stress treatments has shown that the majority of stress-induced genes responded earlier than later stress time points [45]. The present analysis supports this point of view where MAP kinase expression responses to stress were associated at early to middle time points (1-6 hours) for dehydration treatments and 3 hours until 24 hours for salt and hyperosmolarity.

Based on Venn diagram (Figure 3), the analysis of overlapping regions shows that MAP kinase genes are induced and can be classified, on the basis of their expression pattern, into four groups. Firstly, a group of six previously noncharacterized genes was induced under the three stresses. Genes induced only by salinity and hyperosmolarity form the second group with the highest number of induced MAP kinase genes (10 genes). A third and smaller group contains six genes which are induced only by dehydration. The fourth and smallest group contains only two genes which are induced by dehydration and hyperosmolarity. These results indicate that the cross-talking between salinity and hyperosmolarity signalling processes may be greater than those between hyperosmolarity and dehydration which, in turn, may be greater than those between dehydration and salinity signalling processes. This cross-talk might correspond to overlapping between the perception and signal transduction mechanisms of the different abiotic stress sharing common effects [45-47]. Further functional analysis of the corresponding overlapping-induced genes will be helpful to understand these complex stress signal transduction pathways.

Interestingly, none of the 44 studied MAP kinase genes was specifically induced only by salinity or hyperosmolarity conditions, which suggests common signalling pathway between these two stresses. However, it was recently shown that distinct signalling pathways are involved in the tight regulation of proline metabolism with the involvement of 


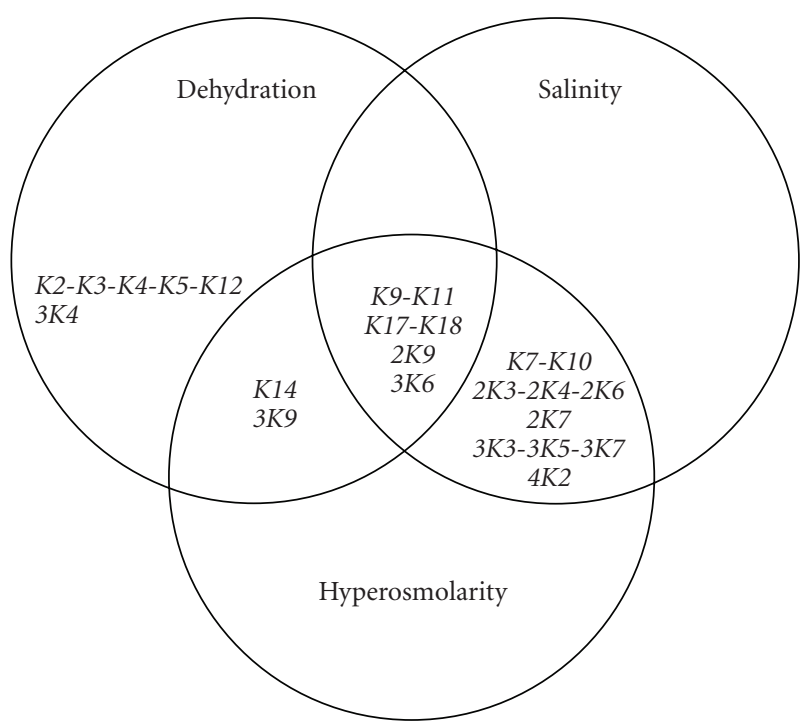

Figure 3: Venn diagram of MAP kinase genes upregulated by water stresses. Names of the genes with $\geq 2.5$-fold change in their expression level in response to dehydration, salinity or hyperosmolarity are indicated. K: MPK; $2 K: M K K ; 3 K: M A P 3 K ; 4 K$ : MAP4K.

phospholipases and calcium upon ionic stress, but not in response to hyperosmotic stress [48].

Most of the water stress-dependant inductions of MAP kinases reported here were not detected in the microarray analysis available in genevestigator (https://www .genevestigator.ethz.ch/) database. For example, for the MKK family, five members were observed here transcriptionally induced, among which only one (MKK9) was also observed in the database. Additionally to the higher sensitivity already mentioned of the macroarrays used here, several kinds of water stresses with several kinetics points were used here, allowing this better detection of transcriptional regulations.

We found that the promoter region of some stressinduced MAP kinase genes, that is, MPK3, MPK5, MPK7, MPK10, MPK18, MPK20, MKK9; MAP3K3, and MAP3K7, contains the cis-acting proline-responsive-element sequence involved in the proline and hypoosmolarity-inducible gene expression $[49,50]$, suggesting that these genes may also respond to hypoosmolarity. However, high transcript level was only observed for MPK20, which belongs to the MPK $\mathrm{D}$ group, in response to hypoosmolarity and recovery conditions.

It is worthy of note that no significant repressed expression was observed for any of the studied MAP kinase genes. In addition, genes having high levels of sequence similarity tend to display similar expression patterns in organs or under stress conditions. For example, all members of the B1 subgroup (MPK4, MPK5, MPK11, and MPK12) were induced by dehydration. However, like in the case of each gene family, it is often supposed that there is a functional redundancy between the gene family members, but this remains to be demonstrated using appropriate techniques. In our conditions, we could not observed any induction of MAP3K8 (At4g08500), anciently known as AtMEKK1 and previously shown to be induced and the corresponding protein to be the upstream activator of MKK in the response to biotic and abiotic stress $[18,21]$. Nevertheless, we could observe the induction of MAP3K9 (Table 3) which is very similar in sequence to $M A P 3 K 8$, suggesting that MAP3K8 and MAP3K9 may be functionally redundant.

The induction of MAP kinase genes under a given condition likely involves a parallel induction or the activation of existing substrates to initiate an appropriate MAP kinase cascade in response to stress. However, information about plant MAP kinase substrates is still poor, but 48 potential substrates of MPK3 and 39 of MPK6 were recently identified [24] indicating the complexity of MAP kinase signalling.

Understanding the molecular and genetic basis of stress tolerance is an important prerequisite step to increase plant tolerance through bioengineering approaches. The stressinduced MAP kinase genes represent important targets for further biochemical characterization and bioengineering approaches towards the creation of stress-resistant genotypes.

To our knowledge, this is the first thoroughly reported work on the expression of Arabidopsis MAP kinase genes in relation to osmotic and dehydration stress. The characterization of the corresponding proteins, the identification of MAP kinase substrates, and the elucidation of the interaction network should supply further information about the components and the role of the MAP kinase cascades in plant adaptation to environmental stresses.

\section{Acknowledgments}

The authors thank Luc Richard for helpful advice concerning macroarray hybridizations, Marie-Jo Droillard for initiation to immunoprecipitation and in-gel kinase assays, and Hélène Barbier-Brygoo for critical reading of the manuscript.

\section{References}

[1] K. Ichimura, K. Shinozaki, G. Tena, et al., "Mitogen-activated protein kinase cascades in plants: a new nomenclature," Trends in Plant Science, vol. 7, no. 7, pp. 301-308, 2002.

[2] D. G. Hardie, "Plant protein serine/threonine kinases: classification and functions," Annual Review of Plant Physiology and Plant Molecular Biology, vol. 50, pp. 97-131, 1999.

[3] S.-F. Fu, W.-C. Chou, D.-D. Huang, and H.-J. Huang, "Transcriptional regulation of a rice mitogen-activated protein kinase gene, OsMAPK4, in response to environmental stresses," Plant \& Cell Physiology, vol. 43, no. 8, pp. 958-963, 2002.

[4] L. Xiong and Y. Yang, "Disease resistance and abiotic stress tolerance in rice are inversely modulated by an abscisic acidinducible mitogen-activated protein kinase," The Plant Cell, vol. 15, no. 3, pp. 745-759, 2003.

[5] N. S. Reyna and Y. Yang, "Molecular analysis of the rice MAP kinase gene family in relation to Magnaporthe grisea infection," Molecular Plant-Microbe Interactions, vol. 19, no. 5, pp. 530540, 2006.

[6] H. Shou, P. Bordallo, J.-B. Fan, et al., "Expression of an active tabacco mitogen-activated protein kinase kinase kinase 
enhances freezing tolerance in transgenic maize," Proceedings of the National Academy of Sciences of the United States of America, vol. 101, no. 9, pp. 3298-3303, 2004.

[7] M. Mayrose, A. Bonshtien, and G. Sessa, "LeMPK3 is a mitogen-activated protein kinase with dual specificity induced during tomato defense and wounding responses," The Journal of Biological Chemistry, vol. 279, no. 15, pp. 14819-14827, 2004.

[8] C. Jonak, S. Kiegerl, W. Ligterink, P. J. Barker, N. S. Huskisson, and H. Hirt, "Stress signaling in plants: a mitogen-activated protein kinase pathway is activated by cold and drought," Proceedings of the National Academy of Sciences of the United States of America, vol. 93, no. 20, pp. 11274-11279, 1996.

[9] F. Baluška, M. Ovecka, and H. Hirt, "Salt stress induces changes in amounts and localization of the mitogen-activated protein kinase SIMK in alfalfa roots," Protoplasma, vol. 212, no. 3-4, pp. 262-267, 2000.

[10] H. Nakagami, A. Pitzschke, and H. Hirt, "Emerging MAP kinase pathways in plant stress signalling," Trends in Plant Science, vol. 10, no. 7, pp. 339-346, 2005.

[11] K. Ichimura, T. Mizoguchi, R. Yoshida, T. Yuasa, and K. Shinozaki, "Various abiotic stresses rapidly activate Arabidopsis MAP kinases ATMPK4 and ATMPK6," The Plant Journal, vol. 24, no. 5, pp. 655-665, 2000.

[12] R. W. Innes, "Mapping out the roles of MAP kinases in plant defense," Trends in Plant Science, vol. 6, no. 9, pp. 392-394, 2001.

[13] M. E. Hoyos and S. Zhang, "Calcium-independent activation of salicylic acid-induced protein kinase and a 40-kilodalton protein kinase by hyperosmotic stress," Plant Physiology, vol. 122, no. 4, pp. 1355-1364, 2000.

[14] M.-J. Droillard, S. Thibivilliers, A.-C. Cazalé, H. BarbierBrygoo, and C. Laurière, "Protein kinases induced by osmotic stresses and elicitor molecules in tobacco cell suspensions: two crossroad MAP kinases and one osmoregulation-specific protein kinase," FEBS Letters, vol. 474, no. 2-3, pp. 217-222, 2000.

[15] M.-J. Droillard, M. Boudsocq, H. Barbier-Brygoo, and C. Laurière, "Different protein kinase families are activated by osmotic stresses in Arabidopsis thaliana cell suspensions: involvement of the MAP kinases AtMPK3 and AtMPK6," FEBS Letters, vol. 527, no. 1-3, pp. 43-50, 2002.

[16] M. Petersen, P. Brodersen, H. Naested, et al., "Arabidopsis MAP kinase 4 negatively regulates systemic acquired resistance," Cell, vol. 103, no. 7, pp. 1111-1120, 2000.

[17] T. Yuasa, K. Ichimura, T. Mizoguchi, and K. Shinozaki, "Oxidative stress activates ATMPK6, an Arabidopsis homologue of map kinase,” Plant \& Cell Physiology, vol. 42, no. 9, pp. 1012-1016, 2001.

[18] T. Asai, G. Tena, J. Plotnikova, et al., "Map kinase signalling cascade in Arabidopsis innate immunity," Nature, vol. 415, no. 6875, pp. 977-983, 2002.

[19] A. Pitzschke and H. Hirt, "Mitogen-activated protein kinases and reactive oxygen species signaling in plants," Plant Physiology, vol. 141, no. 2, pp. 351-356, 2006.

[20] G. L. Johnson and R. Lapadat, "Mitogen-activated protein kinase pathways mediated by ERK, JNK, and p38 protein kinases," Science, vol. 298, no. 5600, pp. 1911-1912, 2002.

[21] K. Shinozaki, T. Mizoguchi, K. Irie, et al., "A gene encoding a mitogen-activated protein kinase kinase kinase is induced simultaneously with genes for a mitogen-activated protein kinase and an S6 ribosomal protein kinase by touch, cold, and water stress in Arabidopsis thaliana," Proceedings of the National Academy of Sciences of the United States of America, vol. 93, no. 2, pp. 765-769, 1996.

[22] K. Ichimura, T. Mizoguchi, K. Irie, et al., "Isolation of ATMEKK1 (a MAP kinase kinase kinase)-interacting proteins and analysis of a MAP kinase cascade in Arabidopsis," Biochemical and Biophysical Research Communications, vol. 253, no. 2, pp. 532-543, 1998.

[23] M. Teige, E. Scheikl, T. Eulgem, et al., "The MKK2 pathway mediates cold and salt stress signaling in Arabidopsis," Molecular Cell, vol. 15, no. 1, pp. 141-152, 2004.

[24] T. Feilner, C. Hultschig, J. Lee, et al., "High throughput identification of potential Arabidopsis mitogen-activated protein kinases substrates," Molecular \& Cellular Proteomics, vol. 4, no. 10, pp. 1558-1568, 2005.

[25] A. D. Catling, S. T. Eblen, H. J. Schaeffer, and M. J. Weber, "Scaffold protein regulation of mitogen-activated protein kinase cascade," Methods in Enzymology, vol. 332, pp. 368-387, 2001.

[26] C. R. Weston, D. G. Lambright, and R. J. Davis, "Signal transduction: MAP kinase signaling specificity," Science, vol. 296, no. 5577, pp. 2345-2347, 2002.

[27] H. Nakagami, S. Kiegerl, and H. Hirt, "OMTK1, a novel MAPKKK, channels oxidative stress signaling through direct MAPK interaction," The Journal of Biological Chemistry, vol. 279, no. 26, pp. 26959-26966, 2004.

[28] T. Tanoue, M. Adachi, T. Moriguchi, and E. Nishida, "A conserved docking motif in MAP kinases common to substrates, activators and regulators," Nature Cell Biology, vol. 2, no. 2, pp. 110-116, 2000.

[29] T. Murashige and F. Skoog, "A revised medium fot rapid growth and bioassays with tobacco tissue cultures," Physiologia Plantarum, vol. 15, no. 3, pp. 473-497, 1962.

[30] D. M. Gibeaut, J. Hulett, G. R. Cramer, and J. R. Seemann, "Maximal biomass of Arabidopsis thaliana using a simple, lowmaintenance hydroponic method and favorable environmental conditions," Plant Physiology, vol. 115, no. 2, pp. 317-319, 1997.

[31] G. M. Church and W. Gilbert, "Genomic sequencing," Proceedings of the National Academy of Sciences of the United States of America, vol. 81, no. 7, part 1, pp. 1991-1995, 1984.

[32] M. M. Bradford, "A rapid and sensitive method for the quantification of $\mathrm{mg}$ quantities of proteins utilising the principle of protein-dye binding," Analytical Biochemistry, vol. 72, no. 1-2, pp. 248-254, 1976.

[33] S. Zhang, H. Du, and D. F. Klessig, "Activation of the tobacco SIP kinase by both a cell wall-derived carbohydrate elicitor and purified proteinaceous elicitins from Phytophthora spp," The Plant Cell, vol. 10, no. 3, pp. 435-450, 1998.

[34] M.-J. Droillard, M. Boudsocq, H. Barbier-Brygoo, and C. Laurière, "Involvement of MPK4 in osmotic stress response pathways in cell suspensions and plantlets of Arabidopsis thaliana: activation by hypoosmolarity and negative role in hyperosmolarity tolerance," FEBS Letters, vol. 574, no. 1-3, pp. 42-48, 2004.

[35] D. J. Lockhart and E. A. Winzeler, "Genomics, gene expression and DNA arrays," Nature, vol. 405, no. 6788, pp. 827-836, 2000.

[36] N. A. Miller, Q. Gong, R. Bryan, M. Ruvolo, L. A. Turner, and S. T. LaBrie, "Cross-hybridization of closely related genes on high-density macroarrays," BioTechniques, vol. 32, no. 3, pp. 620-625, 2002. 
[37] W. Xu, S. Bak, A. Decker, S. M. Paquette, R. Feyereisen, and D. W. Galbraith, "Microarray-based analysis of gene expression in very large gene families: the cytochrome P450 gene superfamily of Arabidopsis thaliana," Gene, vol. 272, no. 1-2, pp. 61-74, 2001.

[38] L. Valério, M. De Meyer, C. Penel, and C. Dunand, "Expression analysis of the Arabidopsis peroxidase multigenic family," Phytochemistry, vol. 65, no. 10, pp. 1331-1342, 2004.

[39] G. F. Steward, B. D. Jenkins, B. B. Ward, and J. P. Zehr, "Development and testing of a DNA macroarray to assess nitrogenase (nifH) gene diversity," Applied and Environmental Microbiology, vol. 70, no. 3, pp. 1455-1465, 2004.

[40] M.-C. Nicole, L.-P. Hamel, M.-J. Morency, N. Beaudoin, B. E. Ellis, and A. Séguin, "MAP-ping genomic organization and organ-specific expression profiles of poplar MAP kinases and MAP kinase kinases," BMC Genomics, vol. 7, article 223, pp. $1-22,2006$.

[41] L.-P. Hamel, M.-C. Nicole, S. Sritubtim, et al., "Ancient signals: comparative genomics of plant MAPK and MAPKK gene families," Trends in Plant Science, vol. 11, no. 4, pp. 192-198, 2006.

[42] T. S. Nühse, S. C. Peck, H. Hirt, and T. Boller, "Microbial elicitors induce activation and dual phosphorylation of the Arabidopsis thaliana MAPK 6," The Journal of Biological Chemistry, vol. 275, no. 11, pp. 7521-7526, 2000.

[43] D. Matsuoka, T. Nanmori, K.-I. Sato, Y. Fukami, U. Kikkawa, and T. Yasuda, "Activation of AtMEK1, an Arabidopsis mitogen-activated protein kinase kinase, in vitro and in vivo: analysis of active mutants expressed in E. coli and generation of the active form in stress response in seedlings," The Plant Journal, vol. 29, no. 5, pp. 637-647, 2002.

[44] R. Desikan, J. T. Hancock, K. Ichimura, K. Shinozaki, and S. J. Neill, "Harpin induces activation of the Arabidopsis mitogen-activated protein kinases AtMPK4 and AtMPK6," Plant Physiology, vol. 126, no. 4, pp. 1579-1587, 2001.

[45] J. A. Kreps, Y. Wu, H.-S. Chang, T. Zhu, X. Wang, and J. F. Harper, "Transcriptome changes for Arabidopsis in response to salt, osmotic, and cold stress," Plant Physiology, vol. 130, no. 4, pp. 2129-2141, 2002.

[46] J.-K. Zhu, "Cell signaling under salt, water and cold stresses," Current Opinion in Plant Biology, vol. 4, no. 5, pp. 401-406, 2001.

[47] J.-K. Zhu, "Salt and drought stress signal transduction in plants," Annual Review of Plant Biology, vol. 53, pp. 247-273, 2002.

[48] E. Parre, M. A. Ghars, A.-S. Leprince, et al., "Calcium signaling via phospholipase $\mathrm{C}$ is essential for proline accumulation upon ionic but not nonionic hyperosmotic stresses in Arabidopsis," Plant Physiology, vol. 144, no. 1, pp. 503-512, 2007.

[49] R. Satoh, K. Nakashima, M. Seki, K. Shinozaki, and K. Yamaguchi-Shinozaki, "ACTCAT, a novel cis-acting element for proline- and hypoosmolarity-responsive expression of the ProDH gene encoding proline dehydrogenase in Arabidopsis," Plant Physiology, vol. 130, no. 2, pp. 709-719, 2002.

[50] R. Satoh, Y. Fujita, K. Nakashima, K. Shinozaki, and K. Yamaguchi-Shinozaki, "A novel subgroup of bZIP proteins functions as transcriptional activators in hypoosmolarityresponsive expression of the ProDH gene in Arabidopsis," Plant \& Cell Physiology, vol. 45, no. 3, pp. 309-317, 2004. 